\title{
Ultrasonographic Biometrical Studies on Reproductive Organs of rbST Treated Pregnant Kundhi Buffaloes
}

\author{
A.B. Kachiwal ${ }^{1}{ }^{1}$, B.A. Sheikh ${ }^{1}$, S.A. Sheikh ${ }^{1}$, K.H. Memon ${ }^{2}$, S. Memon ${ }^{2}$ and T.A. Qureshi ${ }^{1}$ \\ ${ }^{1}$ Sindh Agriculture University Tandojam, Pakistan \\ ${ }^{2}$ Baqai College of Veterinary Sciences, Karachi, Pakistan
}

\begin{abstract}
Biometrical studies were conducted on sixty four gravid uteri with estimated gestation period of 1 st, 2nd, 3rd and 4th month of pregnancy in Kundhi buffaloes. Sixteen specimens for each month of gestation were collected from Hyderabad slaughterhouse to evaluate techniques for measurement of reproductive organs. The measurements for fetometry and morphometry of reproductive organs by ultrasound machine and manually (by measuring tape and vernier caliper) were performed and compared. The Ultrasound examinations were performed through diagnostic ultrasound machine equipped with multi-frequency $5-10 \mathrm{MHz}$ transrectal linear array transducer. Analysis revealed that the ovary, foetus, foetal fluid and uterus progressively increased significantly $(P<0.01)$ in weight during 4th month of the gestation than 1st, 2nd and 3rd month of gestation period in rbST treated Kundhi buffaloes. Ovaries with CL were significantly $(P<0.01)$ heavier than the ovary in which $C L$ was absent. Corpus leutum was significantly lighter $(P<0.01)$ during $1 \mathrm{st}$ month of pregnancy than 2nd, 3rd and 4th month of pregnancy in rbST treated Kundhi buffaloes. Gravid uterus was significantly heavier $(P<0.01)$ during 4 th month of pregnancy than $1 \mathrm{st}$, 2nd and 3rd month of pregnancy in rbST treated Kundhi buffaloes. There was no significant difference between the measurements of oviduct, cervix and vagina during 1st to 4th month of pregnancy. The placenta, foetal fluid and foetus progressively increased significantly in size as gestation period progressed. The ultrasonographic fetometric and morphometric threshold of CRL, TD and UD and foetal weight was steadily increased in rbST treated Kundhi buffaloes. There was significant increase $(P<0.05)$ in the $C R L, T D$, UD and foetus weight/volume at $4^{\text {th }}$ month of pregnancy than $1^{\text {st }}, 2^{\text {nd }}$ and $3^{\text {rd }}$ month of pregnancy in rbST treated Kundhi buffaloes. In conclusion, the overall data indicated that the examination for ultrasonographic fetometry and morphometry of reproductive organs of kundhi buffaloes for evaluation of fetal development, estimation of gestational age and formulation of fetal chart through reproductive organs were more suitable as compare to manual biometrical evaluation.
\end{abstract}

Keyword: Ultrasonar, reproductive organ, rbST, buffaloes.

\section{INTRODUCTION}

Ultrasonography is a safe and non-invasive diagnostic technique in veterinary medicine and better method for detecting reproductive disorders in buffalo [1, 2], sheep [3] and goat [4]. The application of transrectal real-time ultrasonography revolutionized the knowledge of reproductive biology which represents a technological breakthrough for the study of bovine reproduction. Ultrasonic imaging has clarified the nature of complex reproductive processes in cattle including ovarian follicular dynamics, corpus luteum function, and foetal development [5-7] and as a helpful technology for embryo transfer procedures. Reproductive performance is economically very important in buffaloes. The biometry of genital tracts of the female reveals the overall well being of the animals. The knowledge of the biometrical status of female genital tract is essential to perform artificial insemination, pregnancy diagnosis and dealing with the infertility problems [8] and its treatment [9]. Modern technologies for increasing population such as in vitro fertilization (IVF), artificial insemination (AI) requires a

*Address correspondence to this author at the Department of Surgery and Obstetrics, Sindh Agriculture University Tandojam, Pakistan; Tel: +92223405309; Fax: +92-222765300; E-mail: kachiwal2003@gmail.com good knowledge of female reproductive biometry but limited information so far been available on the evaluation of buffalo ovaries and other genital organs [10]. Control of diseases is also very important to ensure good health which also demands normal measurement of different reproductive tracts. Some work on the morphology, physiology and pathology of reproductive organs of buffaloes [1, 2, 11], cow [12,13] and goat $[14,15]$ has been reported in different countries. But very little is known about the morphology of the reproductive tract of rbST treated Kundhi buffaloes.

Therefore, this study was designed to assess the effect of rbST on the anatomy of reproductive organs, developmental stages of foetus and placenta by ultrasound machine and manually.

\section{MATERIALS AND METHODS}

Sixty four specimens ( 16 of each month i.e., $1^{\text {st }}, 2^{\text {nd }}$, $3^{\text {rd }}$ and $4^{\text {th }}$ month gravid reproductive tracts) of pregnant rbST treated Kundhi buffaloes were collected from Hyderabad, Pakistan, slaughterhouse. The genital tracts were brought to the Surgery Hall, Department of Surgery and Obstetrics, Faculty of Animal Husbandry and Veterinary Sciences, Sindh Agriculture University Tandojam, Pakistan. The fatty connective tissues, 
vaginal wall and ligaments were removed, leaving cervix intact. These organs were kept in water filled tray covered all the organs. Fetometry and morphometry of gravid uteri was performed manually and by ultrasound machine. The Ultrasound examinations were performed through diagnostic ultrasound machine (HS-2000, Honda electronics Co. Ltd., Japan) equipped with multi-frequency $5-10 \mathrm{MHz}$ trans-rectal linear array transducer to measure length, breadth and thickness of ovary and corpus luteum $(\mathrm{CL})$. The ovaries were examined for presence of follicles or corpus leutum. Ovaries and corpus leutum was separated and weighted with and without $\mathrm{CL}$ with triple beam balance. Sections were made through each ovary and number, size, shape, color and location of $\mathrm{CL}$ were recorded. The length, breadth and thickness of ovary and $C L$ were recorded and measured by ultrasound machine. The measurements for the length of gravid and non-gravid horn, greater curvature, lesser curvature and circumferences were taken with the help of a measuring tape and ultrasound transducer (Plate 2).

The gravid uterus was measured and weighed and its contents were acquired. The side of pregnancy and trans-uterine migration of ova was noted (if any). The gravid uterine horn along the whole length of greater curvature was incised to exteriorize the foetal sac and foetal fluid was collected in measuring cylinder. The weight of emptied uterus, cervix, foetal membrane and foetus was then taken. The numbers of caruncles were noted separately and weight of individual caruncle of both horns was recorded.

The foetal sacs were stabbed and the quantity of foetal fluid was measured with graduated cylinder. The sex of fetuses was confirmed visually. The crown rump length was calculated through built in program of Ultrasound machine (HS-2000, Honda electronics Co. Ltd., Japan). The crown rump length (CRL), trunk diameter (TD) of fetus and uterine diameter (UD) were

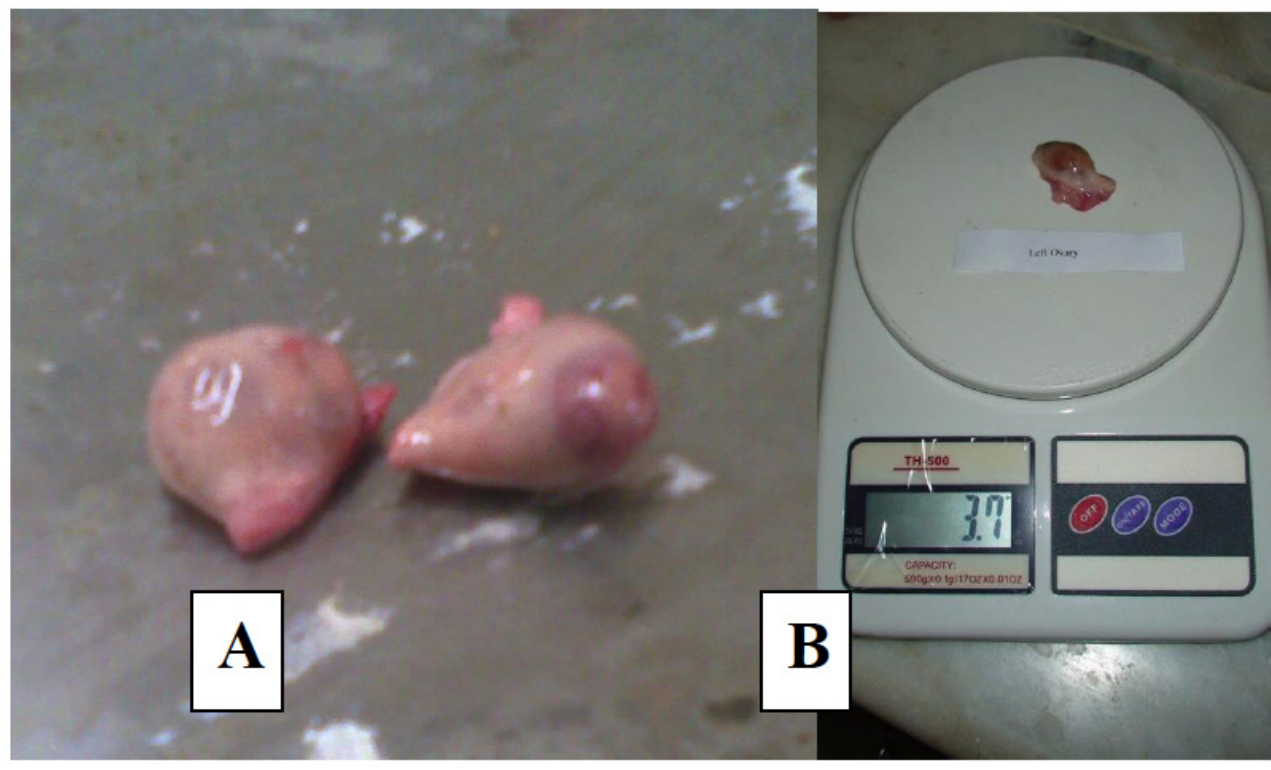

Plate 1: (A) Right ovary with corpus leutum and left ovary with follicles. (B) Weight of left ovary by analytical balance.

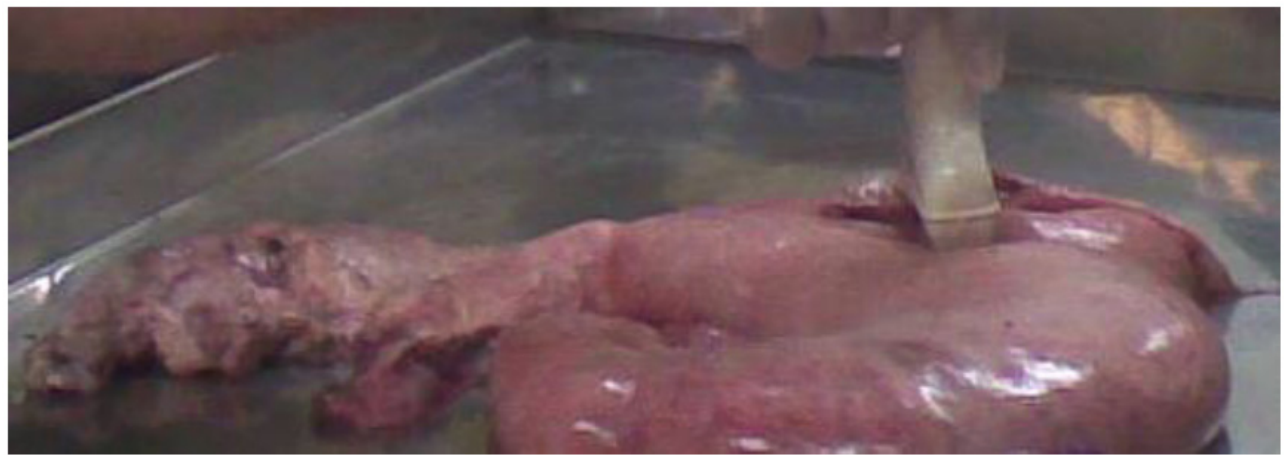

Plate 2: Ultrasonographic fetomery and biometry of uterus of rbST treated pregnant slaughtered Kundhi buffalo. 
measured for assessment of foetal age after dissection. Comparisons were made between crown rump length detected by ultrasound machine and actual crown rump length recorded after dissection. The age of foetus was calculated on the basis of CR-length by manual measurement according to the following formula:

$$
Y=28.6660+4.496 x \text {, }
$$

where $y=$ age ( days) and $\mathrm{x}=\mathrm{CR}$-length (cms) and compared with built in formula of ultrasound (HS-2000, Honda electronics Co. Ltd., Japan).

Examination and biometry of the specimens were carried out under bright light, in addition to examine gross abnormalities (if any). All measurements of the anatomical structure of normal reproductive tract were recorded in centimeter and weights in grams. The length and condition of the cervix were recorded in centimeter from external os to internal os and the diameter calculated from the circumference at the middle portion. The length of the vagina was taken as the distance from external os of the cervix to the ventral commissure of the vulva. A measurement of the vaginal width was regularly taken at a point approximately $3 \mathrm{~cm}$ from the external os of the cervix, prior to extending the dorsal incision through the vagina. For measurement of length and breadth metric system was followed by using scale and measuring tape. Photographs were made for proper illustration of the observations. All measurements were taken with a thin, flexible, graduated tape.

\section{Statistical Analysis}

All measurements were recorded in a tabular form. Then the tabulated data was analyzed for descriptive statistics. The significance between both manual and ultrsonographic measurements were tested using SPSS (version-11).

\section{RESULTS}

The mean length, width, weight, number of follicle and number of corpus luteum (CL) per ovary in Kundhi buffaloes are presented in Table 1. The mean length, circumference and weight of oviduct, uterus, cervix and vagina of kunddhi buffaloes are shown in (Tables 2-4) Analysis revealed that the ovary and uterus progressively increased significantly $(P<0.01)$ in weight during $4^{\text {th }}$ month of the gestation than $1^{\text {st }}, 2^{\text {nd }}$ and $3^{\text {rd }}$ month of gestation period in rbST treated Kundhi buffaloes. Ovaries with $C L$ were significantly $(P<0.01)$ heavier than the ovary in which CL was absent or when $\mathrm{CL}$ was removed. Corpus leutum was significantly lighter $(\mathrm{P}<0.01)$ during $1^{\text {st }}$ month of pregnancy than $2^{\text {nd }}$, $3^{\text {rd }}$ and $4^{\text {th }}$ month of pregnancy in rbST treated Kundhi buffaloes. Gravid uterus was significantly heavier $(P<0.01)$ during $4^{\text {th }}$ month of pregnancy than $1^{\text {st }}, 2^{\text {nd }}$ and $3^{\text {rd }}$ month of pregnancy in rbST treated Kundhi buffaloes. There was no significant difference between biometry performed manually as compared to ultrasonographic measurements. There was no significant difference between the measurements of vulva, cervix, vagina and oviduct during the gestation period of $1^{\text {st }}$ to $4^{\text {th }}$ month of pregnancy. The placenta,

Table 1: Weight and Ultrasonographic Biometric Volume of Ovaries and Corpus Leutums of rbST Treated Pregnant Kundhi Buffaloes

\begin{tabular}{|c|c|c|c|c|}
\hline \multirow{2}{*}{ Observations } & \multicolumn{4}{|c|}{ Gestation Period } \\
\hline & one month & 2 months & 3 months & 4 months \\
\hline Weight of ovary with CL (gm) & $4.6 \pm 0.345^{\text {aa }}$ & $5.9 \pm 1.134^{\mathrm{abbcc}}$ & $6.1 \pm 1.179^{\text {aabb }}$ & $6.5 \pm 1.139^{\text {aadd }}$ \\
\hline Weight of ovary without CL (gm) & $2.7 \pm 0.276^{\mathrm{aabbccdd}}$ & $3.6 \pm 1.145^{\mathrm{bbccdd}}$ & $3.8 \pm 1.04^{\mathrm{dd}}$ & $3.8 \pm 0.821^{\mathrm{bbccdd}}$ \\
\hline Weight of CL (gm) & $2.0 \pm 0.162^{\mathrm{aabb}}$ & $2.4 \pm 0.347^{\mathrm{aabb}}$ & $2.6 \pm 0.266^{\text {aabbcc }}$ & $3.0 \pm 0.494^{\mathrm{aabbcc}}$ \\
\hline Weight of ovary in which CL absent (gm) & $2.7 \pm 0.345^{\text {aabbccdd }}$ & $3.6 \pm 1.140^{\mathrm{bbccdd}}$ & $3.9 \pm 1.149^{\mathrm{bbdd}}$ & $4.2 \pm 1.093^{\mathrm{bbccdd}}$ \\
\hline Volume of ovary with $\mathrm{CL}(\mathrm{um})^{3}$ & $4.94+0.37^{\mathrm{aa}}$ & $6.34+1.22^{\mathrm{abbcc}}$ & $6.55+1.27^{\mathrm{aabb}}$ & $6.99+1.22^{\text {aadd }}$ \\
\hline Volume of ovary without CL (um) ${ }^{3}$ & $2.9+0.30^{\text {aabbccdd }}$ & $3.87+1.23^{\mathrm{bbccdd}}$ & $4.08+1.11^{\mathrm{dd}}$ & $4.08+0.88^{\mathrm{bbccdd}}$ \\
\hline Volume of $\mathrm{CL}(\mathrm{um})^{3}$ & $2.15+0.17^{\text {aabb }}$ & $2.58+0.37^{\mathrm{aabb}}$ & $2.8+0.286^{\text {aabbcc }}$ & $3.22+0.53^{\mathrm{aabbcc}}$ \\
\hline Volume of ovary in which CL absent (um) ${ }^{3}$ & $2.9+0.37^{\text {aabbccdd }}$ & $3.87+1.22^{\mathrm{bbccdd}}$ & $4.19+1.23^{\mathrm{bbdd}}$ & $4.52+1.18^{\mathrm{bbccdd}}$ \\
\hline
\end{tabular}

${ }^{a a}=$ Significantly $(P<0.01)$ different from corresponding values.

${ }^{a}=$ Significantly $(P<0.05)$ different from corresponding values.

${ }^{\mathrm{bb}}=$ Significantly $(P<0.01)$ different from corresponding values.

${ }^{c c}=$ Significantly $(P<0.01)$ different from corresponding values.

dd $=$ Significantly $(P<0.01)$ different from corresponding values. 
Table 2: Fetometry and Biometry of Gravid Uterus of rbST Treated Kundhi Buffaloes

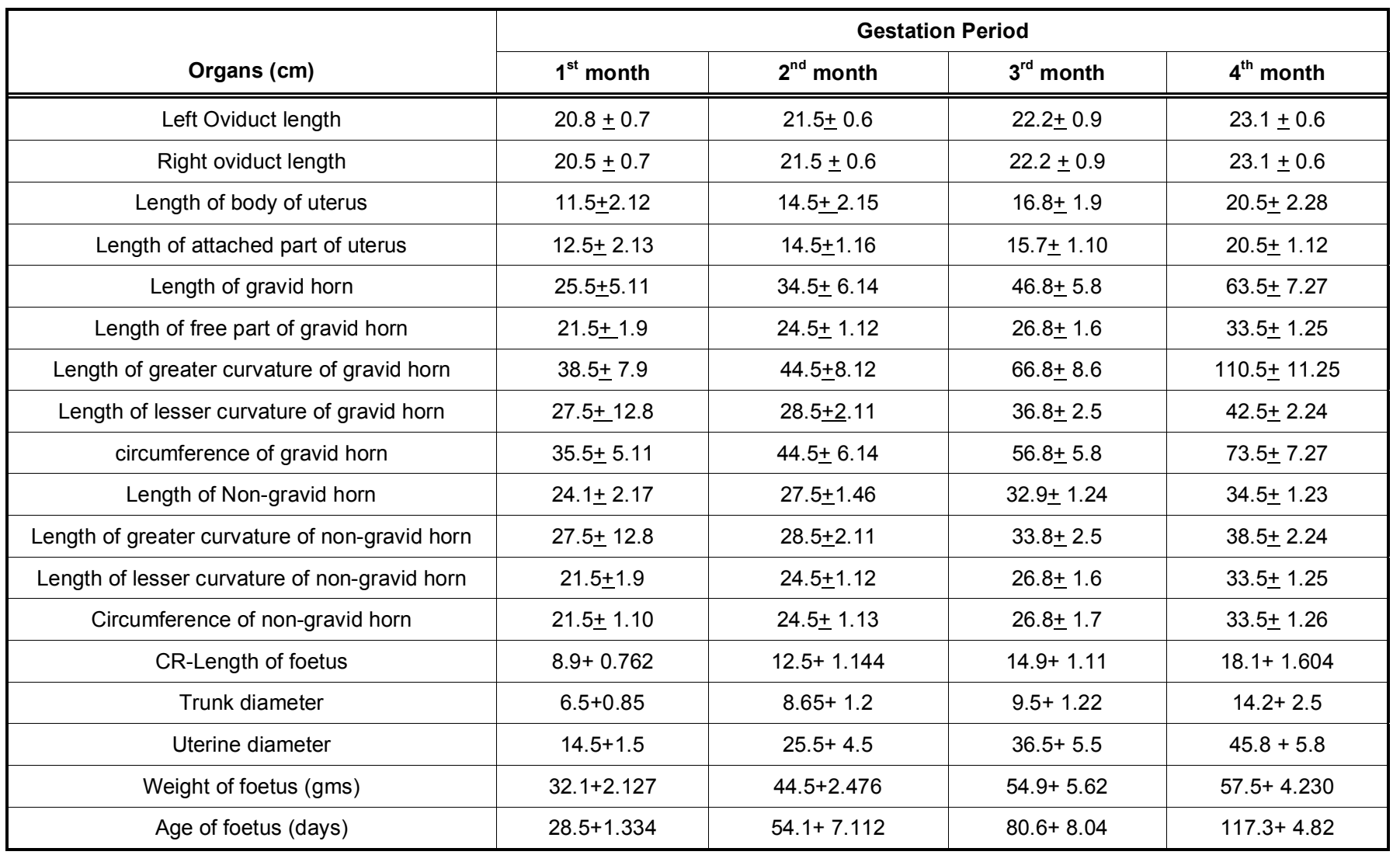

Table 3: Weight of Gravid Uterus and Contents of rbST Treated Kundhi Buffalo

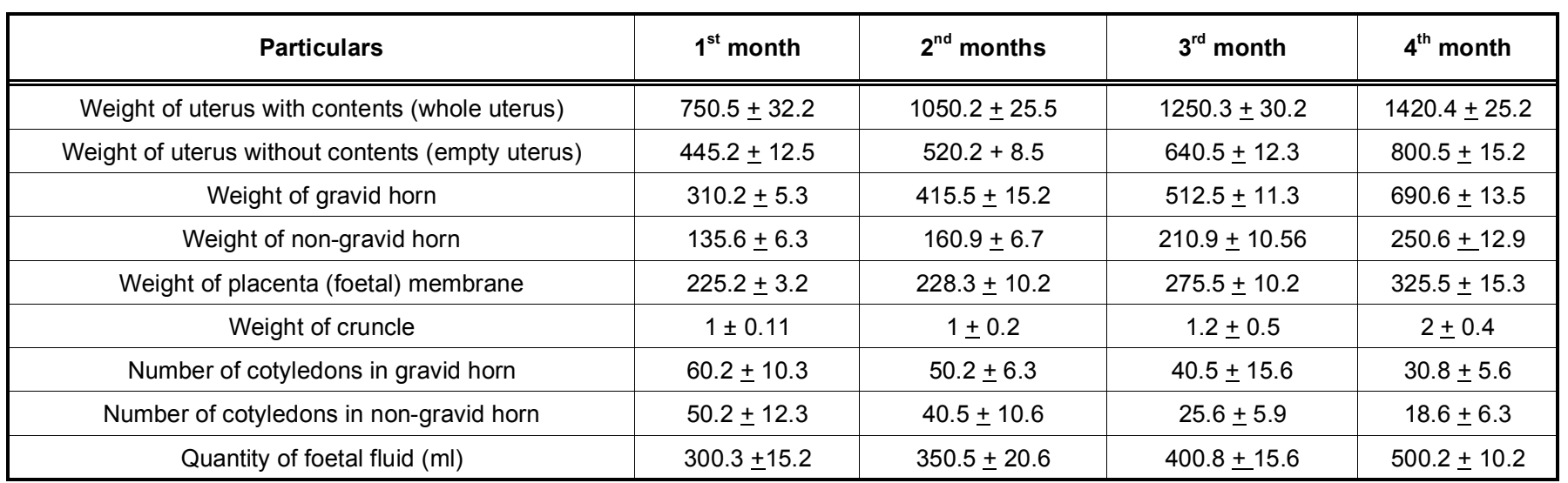

Table 4: Biometry of Cervix and Vagina of rbST Treated Kundhi Buffaloes

\begin{tabular}{|c|c|c|c|c|c|}
\hline \multirow{2}{*}{ Organs } & Measurements & \multicolumn{4}{|c|}{ Gestation Period } \\
\cline { 2 - 6 } & & $\mathbf{1}^{\text {st }}$ month & $\mathbf{2}^{\text {nd }}$ months & $\mathbf{3}^{\text {rd }}$ month & $\mathbf{4}^{\text {th }}$ month \\
\hline \hline \multirow{2}{*}{ Cervix } & Length $(\mathrm{cm})$ & $4.9 \pm 0.1$ & $5.0 \pm 0.1$ & $5.1 \pm 0.11$ & $5.2 \pm 0.13$ \\
& Wideness $(\mathrm{cm})$ & $2.1 \pm 1.1$ & $2.21 \pm 1.1$ & $2.21 \pm 1.1$ & $2.21 \pm 1.1$ \\
\cline { 2 - 6 } & Number of rings & $3.0 \pm 0.2$ & $3.0 \pm 0.2$ & $29 \pm 0.2$ & $3.0 \pm 0.2$ \\
\cline { 2 - 6 } & Length $(\mathrm{cm})$ & $29.4 \pm 0.6$ & $29.5 \pm 0.5$ & $4.2 \pm 0.2$ & $4.3 \pm 0.2$ \\
\hline
\end{tabular}


Table 5: Foetus Measurement Growth Chart of Kundhi Buffaloes

\begin{tabular}{|c|c|c|c|c|}
\hline $\begin{array}{c}\text { Gestation } \\
\text { Period }\end{array}$ & CRL $(\mathbf{c m})$ & TD $(\mathbf{c m})$ & UD (cm) & Foetus Wieght (gms) \\
\cline { 2 - 5 } & Mean \pm SEM & Mean \pm SEM & Mean \pm SEM & Mean \pm SEM \\
\hline \hline $1^{\text {st }}$ month & $5.100 \pm 0.216$ & $2.73 \pm 0.18$ & $10.60 \pm 0.37$ & $559.29 \pm 84.28$ \\
\hline $2^{\text {nd }}$ month & $11.471 \pm 0.138$ & $7.00 \pm 0.22$ & $23.40 \pm 0.34$ & $1578.57 \pm 360.39$ \\
\hline $3^{\text {rd }}$ month & $13.643 \pm 0.288$ & $9.04 \pm 0.26$ & $28.39 \pm 0.19$ & $1750.00 \pm 394.76$ \\
\hline $4^{\text {th }}$ month & $16.114 \pm 0.261$ & $10.60 \pm 0.22$ & $32.44 \pm 0.24$ & $1835.71 \pm 413.03$ \\
\hline
\end{tabular}

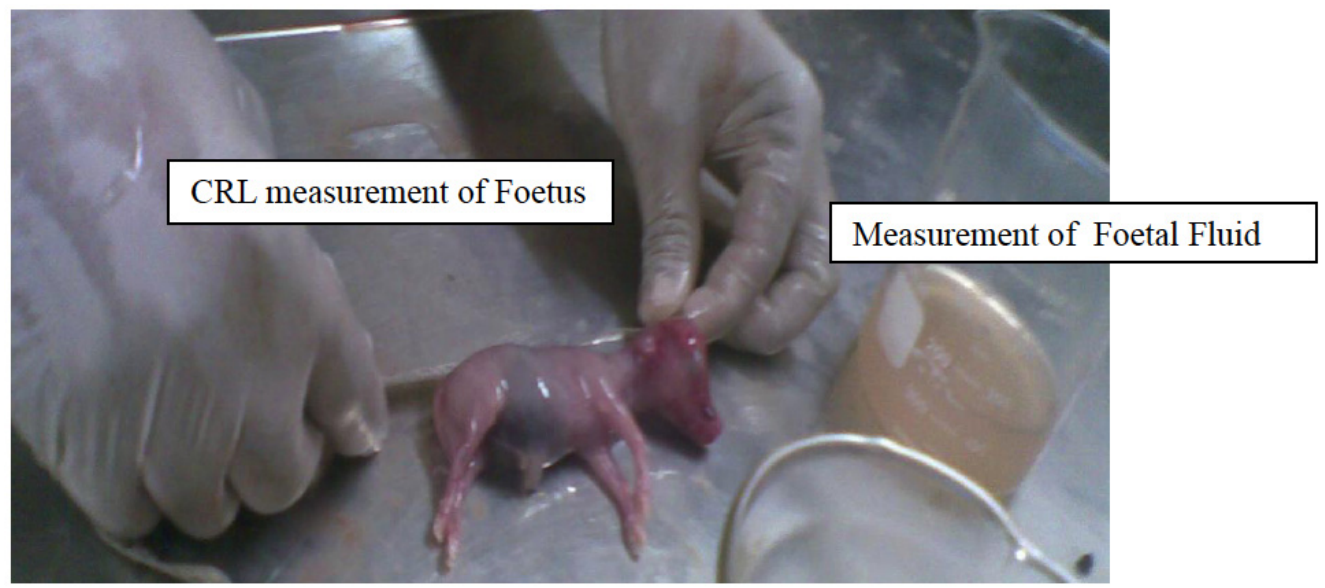

Plate 3: Measurement of foetal fluid with measuring cylinder and CR-length of foetus with measuring tape for gestational age.

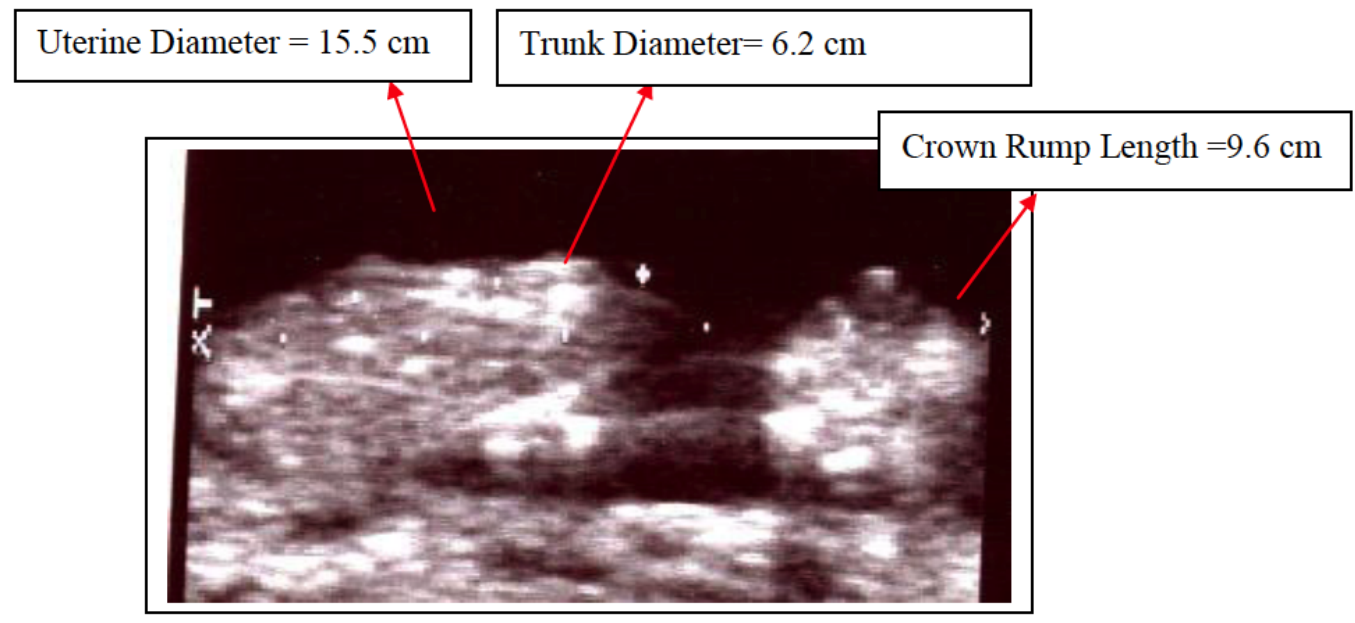

Figure 1: UD, TD and CRL of 30 days Foetus of rbST treated Kundhi buffalo.

foetal fluid and foetus progressively increased significantly in size as gestation period increased (Tables $\mathbf{3} \& \mathbf{5}$ and Plate $\mathbf{3}$ ).

\section{DISCUSSIONS}

The weight and volume of ovary on gravid horn was significantly higher than ovary on non gravid horn of rbST treated Kundhi buffaloes. The mean weight and volume ovaries of Kundhi buffaloes were greater than those observed in non-descript buffaloes by
Chandrahasan and Rajasekaran [16], in Murrah buffaloes by Kumar et al. [9] and in Toda Buffaloes by Patel et al. [2]. The volume of ovary as observed with ultrasonography in this study was higher than that found by Patel et al. [2] in Toda buffaloes, Chandrahasan and Rajsekaran [16] in non-descript buffaloes, Kumar et al. [2] in Murrah buffaloes. Similar weight of ovaries and corpus leutum in Kundhi buffaloes was reported by Kachiwal et al., [10]. Weight and volume of ovaries was significantly increased as pregnancy advanced. Its size normally increases 
Table 6: Biometry of Gravid Uterus and Foetometry in Buffaloes

\begin{tabular}{|c|c|c|c|c|c|c|}
\hline $\begin{array}{l}\text { Gestation } \\
\text { Period }\end{array}$ & $\begin{array}{l}\text { Length of gravid } \\
\text { horn }(\mathrm{cm})\end{array}$ & $\begin{array}{l}\text { Length of non- } \\
\text { gravid horn }(\mathrm{cm})\end{array}$ & $\begin{array}{c}\text { Weight of } \\
\text { gravid uterus } \\
\text { (gms) }\end{array}$ & $\begin{array}{l}\text { Weight of non- } \\
\text { gravid uterus } \\
\text { (gms) }\end{array}$ & $\begin{array}{l}\text { Length of } \\
\text { greater } \\
\text { curvature of } \\
\text { gravid horn }(\mathrm{cm})\end{array}$ & $\begin{array}{l}\text { Length of fetus } \\
\mathrm{CR}(\mathrm{cm})\end{array}$ \\
\hline $1^{\text {st }}$ month & 25.25 & 22.28 & $420.25-517.5$ & $225.0-385.0$ & - & 0.5 \\
\hline $2^{\text {nd }}$ month & 37.60 & 26.21 & $795.73-977.43$ & $461-533$ & $\begin{array}{c}48.97 \pm 3.83 \text { to } \\
63.47 \pm 70.7\end{array}$ & 7.7 \\
\hline $3^{\text {rd }}$ month & 45.6 & 24.72 & $1532-1591$ & 600 & - & $10.72-14.30$ \\
\hline $4^{\text {th }}$ month & 71.85 & 35.85 & 2596.3 & - & - & More than 20 \\
\hline
\end{tabular}

(Data from Abdel Raouf and El-Naggar [19]; Luktuke [20]; Dhaliwal et al., [21]; Khan et al., [22]; Rajasundaram et al., [23]; Amle et al., [24]; Rahamatullah et al., [25]; Ferreira et al., [26] and Pawshe and Purohit [27].

during early stage of pregnancy but the variation in size may be due to variation of breed, age, size of animals, environment and genetic makeup.

Waheed [17] observed that the corpus luteum enlarged as pregnancy advanced and produced progesterone to help in the maintaining of the lining of the endometrium in early pregnancy. Thomas [18] observed that when the placenta was capable of producing adequate amounts of progesterone and estrogen, corpus leuteum slowly decreased in size and function after the 10 th to $12^{\text {th }}$ week of pregnancy. The size of CL was larger in this study than those studied by Honparkhe et al. [11] and Chandrahasan and Rajsekaran [16]. In conclusions, there was significant increase in the size, weight and volume of ovaries and corpus leutum as pregnancy advances than nonpregnant buffaloes. A greater number of ovarian structure (follicles) was found at the time of oestrus than anoestrus period

The ultrasonographic appearance of different structures in different studies shown in (Table 6) reveals that fetometry and biometry of reproductive organs of rbST treated pregnant Kundhi buffaloes were greater than those observed in non-descript buffaloes by other researchers.

The average number and size of cotyledons observed in gravid and non-gravid horn during $1^{\text {st }}, 2^{\text {nd }}$, $3^{\text {rd }}$ and $4^{\text {th }}$ month of pregnancy in Kundhi buffaloes was similar as reported by Pawshe and Purobit [27]. The average quantity of foetal fluid accordingly during $1^{\text {st }}$, $2^{\text {nd }}, 3^{\text {rd }}$ and $4^{\text {th }}$ month of pregnancy in Kundhi buffaloes was similar to the observations by Abdel Raouf and ElNaggar [19]; Luktuke [20]; Dhaliwal et al. [21]; Khan et al. [22]; Rajasundaram et al. [23]; Amle et al., [24]; Rahamatullah et al., [25]; Ferreira et al., [26] and Pawshe and Purohit [27]. The measurements taken by the use of ultrasound were more suitable than conventional methods, Similar findings were observed by Joseph et al. [28] that ultrasonography can provide a non-invasive accurate diagnosis of liver steatosis and fibrosis as compare to conventional method of liver histology.

\section{REFERENCES}

[1] Rohilla N, Singh U, Sharma RK, Singh I. Ultrasonic ovarian status. Indian J Anim Reprod 2005; 26(2): 95-8.

[2] Patel DV, Anil Kumar R, lyue M, Kasiraj R. Ultrasonographic biometry. Buffalo Bulletin 2009; 28(2): 67-72.

[3] Anwar M, Riaz A, Ullah N, Rafiq M. Use of ultrasonography. Pak Vet J 2009; 28(3): 144-6.

[4] Medan M, Watanabe G, Absy G, Sasaki K, Sharaway S, Taya K. Early pregnancy diagnosis. J Rep D 2004; 50(4): $391-7$

http://dx.doi.org/10.1262/jrd.50.391

[5] Pieterse MC, Kappen KA, Kruip TA, Taverne MAM. Aspiration of bovine oocytes during transvaginal ultrasound scanning of the ovaries. Theriogenology 1988; 30: 751-762. http://dx.doi.org/10.1016/0093-691X(88)90310-X

[6] Pieterse MC, Vos PLAM, Kruip TA, Wurth YA, van Beneden $\mathrm{TH}$, Willemse $\mathrm{AH}$, Taverne MAM. Transvaginal ultrasound guided follicular aspiration of bovine oocytes. Theriogenology 1991; 35: 19-24.

http://dx.doi.org/10.1016/0093-691X(91)90144-3

[7] Meintjes M, Bellow MS, Broussard JR, Paul JB, Godke RA Transvaginal aspiration of bovine oocytes from hormonetreated pregnant beef cattle for IVF. Theriogenology 1993; 39: 266.

\section{http://dx.doi.org/10.1016/0093-691X(93)90121-K}

[8] Kumbar HK, Samo MU, Memon A, Solangi AA. Biometrical studies of reproductive organs of Thari cow. Pakistan J Biological Aci 2003; 6(4): 322-324.

[9] Kumar S, Ahmed FA, Bhadwal MS. Biometry of female genitalia of Murrah buffalo (Bubalus bubalus). Indian J Anim Reprod 2004; 25(2): 143-145.

[10] Kachiwal AB, Sheikh BA, Sheikh SA, Qureshi TA Ultrasonographic biometry of the ovaries of pregnant Kundhi buffalo. J Buffalo Sci 2012; 1: 188-192.

[11] Honparkhe M, Gandotra VK, Nanda AS, Prabhakar S. A comparison of rectal palpation. Indian J Anim Reprod 2003; 24(2): 149-51.

[12] Hanzen $\mathrm{CH}$, Pietrse $\mathrm{M}$, Scenezi $\mathrm{O}$, Drost $\mathrm{M}$. Relative accuracy. The Vet J 2000; 159: 161-70. http://dx.doi.org/10.1053/tvil.1999.0398

[13] White IR, Russel AJF, Wright IA, Whyte TK. Real-time ultrasonic scanning in the diagnosis of pregnancy and 
estimation of gestational age in cattle. Vet Rec 1985;

117: 5-8.

http://dx.doi.org/10.1136/vr.117.1.5

[14] Adigwe PI, Fayemi O. A biometric study of the reproductive tract of the red sokoto (Maradi) goats of Nigeria. Pak Vet $\mathrm{J}$ 2005; 35(3).

[15] Simoes J, Almeida JC, Baril G, Azvedo J, Fontes P, Mascarenhas R. Assessment of luteal function. Anim Rep Sci 2007; 97: 36-46.

[16] Chandrahasan C, Rajasekaran J. Biometry of buffalo. Indian J Anim Reprod 2004; 25(2): 87-90.

[17] Waheed MM. Ovarian activity and hormonal relationships in pregnant buffaloes. Buffalo Bulletin 2011; 30(1): 55-99.

[18] Thomas PGA. Induced abortion, In Youngquist RS, Ed. Current Therapy in Large Animal Theriogenology. W.B. Saunders Company, USA 1997; pp. 303-306.

[19] Abdel Raouf M, El-Naggar M. The biometry of the gravid uterus in Egyptian buffalo cows. Zentralbl Veterinarmedizin 1968; 13A: 252-263.

[20] Luktuke SN. Studies on prenatal development of buffalo. Indian Vet J 1983; 60: 38-41.

[21] Dhaliwal GS, Dugwekar YG, Sharma RD. The pelvimetry in buffaloes (Bos bubalis) during pregnancy and puerperium. Indian J Anim Reprod 1982; 2: 32-34.
[22]

Khan MZ. Biometrical studies on sexual organs in early pregnancy of Nili Ravi buffaloes. Indian J Anim Sci 1989; 59: 446-449.

[23] Rajasundaram RC, Kathiresan D, Pattabiraman SR. Changes in biochemical constituents of allantoic and amniotic fluids with the increase in gestation period in buffaloes. Indian J Anim Reprod 1990; 11: 24-28.

[24] Amle MB, Chinchkar SR, Hukeri VB, et al. Studies on fetal fluids of buffaloes. Indian J Anim Reprod 1992; 13: 165-167.

[25] Rahamatullah R, Brohi MA, Rind MI. Fetal growth patterns and weight gain of uterus during gestation in buffaloes (Bubalus bubalis). Pak Vet J 2000; 20: 197-199.

[26] Ferreira GJ, Branco E, Cabral R, et al. Morphological aspects of buffaloes (Bubalus bubalis) umbilical cords. Pesq Vet Bras 2009; 29: 788-792. http://dx.doi.org/10.1590/s0100-736x2009001000002

[27] Pawshe $\mathrm{CH}$, Purohit GN. Approaches for diagnosis of pregnancy in female buffaloes. In: Bubaline Theriogenology, Purohit G.N. and Borghese A. (Eds.). International Veterinary Information Service, Ithaca NY (www.ivis.org) 2013.

[28] Joseph AEA, Saverymuttu SH, Al-Sam S, Cook MG, Maxwel JD. Comparison of liver histology with ultrasonography in assessing diffuse parenchymal liver disease. Clin Radiol 1991; 43(1): 26-31. http://dx.doi.org/10.1016/S0009-9260(05)80350-2 